\title{
A REVERSIBILIDADE DA TUTELA POSSESSÓRIA NA POLÍTICA PÚBLICA DE REFORMA AGRÁRIA
}

The reversibility of the custody for possession in public policy on agrarian reform

Mariana Barbosa Cirne ${ }^{1}$

\begin{tabular}{|c|c|}
\hline RESUMO & ABSTRACT \\
\hline $\begin{array}{l}\text { O presente artigo pretende realizar uma } \\
\text { pesquisa no âmbito do direito processual civil } \\
\text { sobre o instituto da posse, e a rua } \\
\text { antecipação, no contexto da ação de } \\
\text { desapropriação por interesse social para fins } \\
\text { de reforma agrária, prevista no artigo } 6^{0} \text {, I, da } \\
\text { Lei Complementar no } 76 / 93 \text {. Almeja-se tratar } \\
\text { da política pública para adentrar na } \\
\text { delineação da posse para em seguida tratar } \\
\text { sobre a possibilidade de sua imissão } \\
\text { antecipada, nas particularidades de um } \\
\text { procedimento especial em desapropriação, } \\
\text { levando-se em conta o conceito de } \\
\text { reversibilidade da medida e o interesse } \\
\text { público envolvido. Além disso, busca-se } \\
\text { elucidar os entraves encontrados pelo INCRA } \\
\text { para desenvolver essa política pública em } \\
\text { decorrência da compreensão judicial sobre o } \\
\text { instituto. Ao se verificar a existência de um } \\
\text { problema } \\
\text { desapropriações por interesse social para fins } \\
\text { de reforma agrária, por limitações à imissão } \\
\text { na posse) espera-se propor uma reflexão } \\
\text { sobre a antecipação de tutela, no intuito de } \\
\text { tornar possível a política pública. }\end{array}$ & $\begin{array}{l}\text { This paper attempts to conduct a search in the } \\
\text { civil procedural law about the institution of } \\
\text { possession, and its anticipation in the context } \\
\text { of expropriation action for social interest for } \\
\text { the agrarian reform, provided for in Article } 6 \text {, } \\
\text { I, Complementary Law number } 76 / 93 \text {. It is } \\
\text { intended to analyze the public policy to enter } \\
\text { in the contours of the possession to then treat } \\
\text { the possibility of its anticipation, the } \\
\text { particularities of the specific procedure of the } \\
\text { expropriation, together with the concept of } \\
\text { reversibility and the public interest involved. } \\
\text { Furthermore, it aims to elucidate the obstacles } \\
\text { faced by INCRA to develop this public } \\
\text { policy, because of the judicial understanding } \\
\text { about the institute. To verify the existence of } \\
\text { a problem (non-effectiveness of expropriation } \\
\text { for social interest to agrarian reform, because } \\
\text { of the limitations on the writ in possession) is } \\
\text { expected to propose a reflection, related to } \\
\text { the anticipation of possession, with the } \\
\text { objective of turning the public policy into } \\
\text { possible. }\end{array}$ \\
\hline $\begin{array}{l}\text { Palavras-chave: Desaprol } \\
\text { agrária; antecipação da tut }\end{array}$ & $\begin{array}{l}\text { n, } \\
\text { rever }\end{array}$ \\
\hline
\end{tabular}

\footnotetext{
${ }^{1}$ É bacharela em direito pela UFPE, especialista em direito constitucional pela UNP e em processo civil pelo IDP, e mestre em direito constitucional pela UNB, além de pesquisadora do grupo sociedade, tempo e direito da mesma instituição. É procuradora federal e professora de direito constitucional. Coordena o Centro de Estudos Jurídicos da Presidência da República. marianabcirne@gmail.com
} 
37

\section{INTRODUÇÃO}

A política de reforma agrária é um mecanismo essencial para a efetivação de direitos sociais previstos na Constituição Federal. Em especial, dentre os direitos previstos no artigo $6^{\text {o }}$ (sexto), destaca-se como uma maneira de efetivar a assistência aos desamparados, ao promover os assentamentos rurais.

Mas, não basta estudar a política pública, e os direitos que esta pode concretizar. É preciso também apreender os instrumentos que podem torná-la efetiva.

Nesse contexto, merecerá especial atenção deste trabalho a urgência imprimida no artigo 6, I, da Lei Complementar $n^{\circ} 76 / 93$ que determina a emissão na posse do INCRA, no processo de desapropriação para fins de reforma agrária, como instrumento a viabilizar com urgência os assentamentos.

Neste contexto, como corte metodológico, merecerá especial atenção a imissão antecipada da posse, tema central deste trabalho. Para fazer o estudo, pretende-se apurar os contornos da tutela da posse e as particularidades de tal instituto no contexto da política de desapropriação para a reforma agrária, levando-se em conta a existência de um rito sumário e de um contraditório especial. No âmbito processual, almeja-se ainda adentrar na possibilidade de concessão antecipada da tutela e a sua reversibilidade, à luz de uma visão mais progressista do processo, acolhida por autores como Luiz Guilherme Marinoni e outros processualistas que trabalham com o tema.

Outro aspecto relevante a ser oferecido neste trabalho é um quadro atual, fornecido pelo INCRA, dos empecilhos causados por decisões judiciais à política pública, bem como dados do IBGE referentes à existência, ou não, de necessidade de uma atuação estatal quanto à reforma agrária no Brasil.

Passando pelos pontos já acima delimitados - necessários para um estudo de processo civil conjugado com direito agrário - espera-se fornecer um quadro que espelhe o contexto fático das imissões na posse das desapropriações interesse social para fins de reforma agrária à luz de uma doutrina processual mais moderna. Almeja-se, assim, mostrar um problema dentro da política pública e pensar em formar de concretizar esses direitos. 


\section{OS DIREITOS SOCIAIS E A REFORMA AGRÁRIA}

Um dos exemplos de proposta progressiva, encampada pela Constituição Federal de 1988, inegavelmente foi a bandeira da reforma agrária. Diante de uma realidade fundiária brasileira excludente, uma das formas de concretizar direitos como a moradia, a propriedade, alimentação, foi inegavelmente materializado pela desapropriação por interesse social para fins de reforma agrária prevista no artigo 184 da CF.

Em um só dispositivo constitucional, atribuiu-se a competência da desapropriação por interesse social à União; delimitou em que hipótese tal procedimento judicial será possível: quando o imóvel rural não cumprir a sua função social; e determinou-se o pagamento de justa indenização prévia $^{2}$. A Constituição trouxe expressos em apenas um artigo, portanto, a competência, a hipótese legal e a contrapartida a ser prestada pelo Estado na desapropriação por interesse social para fins de reforma agrária. Ao mesmo tempo, abriu aqui a possibilidade de criação doas assentamentos agrários.

Para que não existissem excessos quanto ao pagamento em parcelas (títulos da dívida pública) da justa indenização, há, no $\S 1^{\circ}$ do artigo 184 da Constituição Federal, ressalva quanto ao pagamento em dinheiro das benfeitorias úteis e necessárias. Criou-se, assim, um regime dúplice para a forma de pagamento da desapropriação por interesse social para fins de reforma agrária: o valor da terra nua será pago por meio de TDAs $^{3}$ (títulos da dívida agrária) e o valor das benfeitorias será adimplido em dinheiro.

O direito à propriedade está materializado no artigo $5^{\circ}$, inciso XXII, mas, está condicionado à previsão do inciso seguinte: “XXIII - a propriedade atenderá a sua função

\footnotetext{
${ }^{2}$ Note-se que há quem defenda que a indenização a ser paga em uma ação de desapropriação por interesse social não pode ser compreendida como prévia, pois, o pagamento das TDAs - títulos da dívida agrária - será realizado no prazo de 20 anos. Cf. SALLES, 2006, p. 902-903. Não se adota tal posição neste trabalho, afinal, nos termos do art. $5^{\circ}$, inciso $\mathrm{V}$, da $\mathrm{LC} \mathrm{n}^{\circ} 76$, de 1993 , é exigido, quando se propõe a desapropriação por interesse social para fins de reforma agrária, o prévio depósito das TDAs. Não bastasse isso, as TDAs são títulos de crédito pro soluto, que circula no comércio. (RSTJ 25/257).

${ }^{3}$ Parece interessante registrar que Antônio Moura Borges é professor e advogado na área agrária de Mato Grosso do Sul há 39 anos, e, quando fala sobre as TDAS, em seu curso de direito agrário, indica-os como o único título garantido pela Constituição Federal e que tem muita procura no mercado de valores por parte de investidores e pessoas interessadas em adquiri-lo com certo deságio. Cf. BORGES, 2007, pp. 667/668.
} 
social"4 . Aqui, o princípio da função social da propriedade está inserido dentro da própria concepção da propriedade e tem como norte uma situação de bem-estar tanto do titular como da sociedade (MARQUESI, 2009, p 37).

Dentro ainda do texto da Constituição Federal de 1988 houve a preocupação com o procedimento a ser levado a efeito na desapropriação por interesse social para fins de reforma agrária. Tanto é assim que no texto constitucional estão delimitadas algumas das características próprias da desapropriação por interesse social para fins de reforma agrária, conferindo-se à lei complementar a definição específica de como se daria o procedimento e o contraditório especial a ser processado perante o Poder Judiciário:

Art. $184(\ldots)$

$\S 2^{\circ}$ - O decreto que declarar o imóvel como de interesse social, para fins de reforma agrária, autoriza a União a propor a ação de desapropriação.

$\S 3^{\text {o }}$ - Cabe à lei complementar estabelecer procedimento contraditório especial, de rito sumário, para o processo judicial de desapropriação. (grifo nosso)

Ao conferir a regulamentação do procedimento especial para uma lei complementar, o constituinte aproveitou o ensejo para determinar que na expropriação agrária houvesse um contraditório especial e um rito sumário. Em outras palavras, primou por prestigiar a celeridade a ser empregada em uma ação de desapropriação por interesse social, levando em conta o objetivo de concretizar a reforma agrária.

\footnotetext{
${ }^{4}$ Merece menção que este estudo parte da premissa de que a função social está dentro do conceito de propriedade, não havendo aqui qualquer conflito dentre os institutos. Nesse sentido, Garcia de Enterrìa e Tomás Ramon Fernandes pontuam que "La propriedad nos es, evidentemente, um derecho absoluto y, exactamente igual que todos los derechos, há de servir a uma necessidad colectiva para subsistir o mantenerse (...). Cf. ENTERRÍA; FERNANDEZ, 1997, p. 221. Tratando sobre o direito de propriedade, na Constituição Federal brasileira, Marcelo Sciorilli aduz que "o direito de propriedade, em nosso ordenamento jurídico, só encontra guarida se e quando exercido segundo a sua função social”. Em: SCIORILLI, 2007, p. 84. No entanto, há quem defenda que exista aqui um conflito entre o direito de propriedade e o exercício de seu interesse social, o que demandaria um "complexo juízo de ponderação entre princípios contrapostos". Nesse sentido: MENDES; COELHO; BRANCO, 2007, p. 1291. No entanto, mais uma vez se registre que essa não é a posição acolhida neste trabalho.
} 
Nos termos da Lei Complementar $n^{0} 76$, de 1993, a desapropriação por interesse social para fins de reforma agrária é composta por duas fases distintas: uma administrativa e outra judicial. Mas, o que de fato mais interessa ao presente estudo é a determinação contida no artigo $6^{\circ}$, da Lei Complementar $n^{\circ} 76$, de 1993, após a alteração realizada pela Lei Complementar $n^{\circ} 88$, de 1996:

Art. $6^{\circ} \mathrm{O}$ juiz, ao despachar a petição inicial, de plano ou no prazo máximo de quarenta e oito horas:

I - mandará imitir o autor na posse do imóvel; (Redação dada pela Lei Complementar $\mathrm{n}^{\circ} 88$, de 1996). (grifo nosso)

De forma categórica, a Lei Complementar nº 76/93 determina que o Poder Público aqui representado pelo INCRA - seja imitido na posse do imóvel no primeiro despacho judicial da petição inicial. Note-se que, antes, era necessária a autorização judicial para o depósito em juízo, seguida da citação para o expropriado contestar. Contudo, com a alteração proporcionada pela Lei Complementar $n^{\circ} 88 / 96$, a imissão do autor na posse é a primeira determinação judicial a ser efetivada em juízo. Eis aqui um dos desmembramentos do contraditório especial e do rito sumário na desapropriação por interesse social para fins de reforma agrária.

A alteração proporcionada pela Lei Complementar $n^{\circ} 88$, de 196, pretendeu $\operatorname{agilizar}^{5}$ o procedimento expropriatório, especialmente para a "rápida obtenção da imissão na posse" (HARADA, 2007, p. 24). Endossando que este deve ser o primeiro provimento judicial, Marcelo Sciorilli (2007, p. 166) sublinha que “(...) ao despachar a petição inicial, e uma vez efetuado o depósito da indenização, o juiz mandará imitir o autor na posse do imóvel, determinará a citação do expropriando para contestar o pedido e expedirá mandado ordenando a averbação do ajuizamento da ação no registro do imóvel, para conhecimento de terceiros (art. $6^{\circ}$ da LC n. 76/1993)".

\footnotetext{
${ }^{5}$ Interessante explicar que no direito comparado, os autores que trataram do processo agrário sempre realizaram uma abordagem pensando em como agilizar o seu procedimento. Nesse sentido, Cappelletti defendia a necessidade alcançar um processo mais rápido, mais econômico e menos formal, com um procedimento sumário, fundado pelo princípio inquisitivo. Em "El problema procesal del derecho Agrario a luz de las tendencias planificadoras de las Constituciones modernas."Cf. CHACÓN, 2000, p. 53.
} 
Não bastasse a determinação da emissão na posse, existem ainda dois outros dispositivos que tornam o procedimento da desapropriação por interesse social para fins de reforma agrária bastante peculiar. O primeiro deles, que merece menção, é o artigo $9^{\circ}$ da Lei Complementar $n^{\circ}$ 76/93: “Art. $9^{\circ}$ A contestação deve ser oferecida no prazo de quinze dias e versar matéria de interesse da defesa, excluída a apreciação quanto ao interesse social declarado." (grifo nosso).

Aqui, o dispositivo expressamente veda a apreciação do interesse social declarado na desapropriação por interesse social para fins de reforma agrária. No entanto, como se demonstrará, a tutela da posse, como medida irreversível, tem evitado a aplicação do dispositivo e evitado a concretização da política pública.

\section{A IMISSÃO NA POSSE NA AÇÃO DE DESAPROPRIAÇÃO POR INTERESSE SOCIAL PARA FINS DE REFORMA AGRÁRIA}

Apesar do artigo $6^{\circ}$, I, da Lei Complementar $n^{\circ} 76 / 93$ ser categórico quanto ao deferimento da imissão na posse no bojo da ação de desapropriação para fins de reforma agrária, com pauta na ideia de irreversibilidade a medida não tem sido deferida, motivo pelo qual parece pertinente a este trabalho estudar os institutos da posse e da antecipação de tutela.

\subsection{A posse}

Aquilo que está reproduzido nos diversos diplomas processuais - a exemplo da Lei Complementar $n^{\circ} 76 / 93$ - e de direito material - como é o caso do Código Civil de 1916 e 2002 - quanto à posse remonta a uma discussão entre dois autores do século XVIII: Savigny e Jhering. Em linhas gerais, a divergência dentre estes dois autores definiu os contornos da posse em diversos ordenamentos jurídicos, dentre eles o brasileiro.

O desenvolvimento do conceito de posse centrou-se, então, em dois elementos: o corpus e o animus $^{6}$, que receberam interpretações distintas por Savigny e Jhering. No entanto, é possível também identificar pontos em comum nas duas teorias: ambas trabalham com a idéia de uma situação de fato e partem da premissa de que em toda posse há uma coisa e uma vontade (PEREIRA, 2003, p. 17).

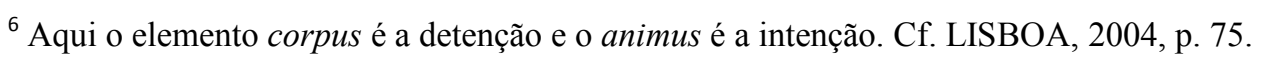


As posições firmadas na divergência doutrinária foram denominadas: subjetiva (para a concepção advogada por Fréderic Charles de Savigny) e objetiva (para a posição defendida por Rudolph Von Jhering) ${ }^{7}$. Nas próximas linhas, pretende-se apresentar os contornos gerais de cada uma de tais correntes doutrinárias.

Em linhas gerais, o que Savigny antevê como corpus é o elemento material da posse, que é a faculdade real e imediata de dispor fisicamente da coisa. Quanto ao elemento interior - animus - Savigny defende que este é a vontade de ter a coisa como sua (PEREIRA, 2003, p. 19). A posse é o poder exercido sobre a coisa com a intenção de tê-la para si (LISBOA, 2004, P. 75). Contudo, o problema identificado pela doutrina em tal postura seria o de que aquele que detêm a coisa, em nome de outrem, não se intitularia jamais como titular da posse, mas, sim de mera detenção.

Quando Jhering tratou sobre a tutela da posse, inicialmente, fez questão de estabelecer uma distinção entre ela e a propriedade. Como meio de introduzir o tema, primeiro explicou que é comum a confusão dentre os dois institutos. Mas, para Jhering (1974, p. 51), a distinção merecia ser feita inicialmente assim: “A posse é o poder de fato, e a propriedade é o poder de direito sobre a coisa". Logo, a posse poderia estar na pessoa que detém a propriedade, ou não.

Mas, segundo Jhering (1974, p. 51), a diferença não tornava os institutos (posse e propriedade) estanques. Quando trabalha essa relação, ele esclarece que "a utilização econômica da propriedade tem a posse como condição". Logo, não se deixa de ver um condão de ligação entre a propriedade e a posse, contudo, isso não faz com que se possam confundir os institutos. Comentando essa relação, no direito agrário, Getúlio Targino Lima (1992, p. 23) afirma que "observa-se uma autonomia da posse que, contraditoriamente, esbarra, de algum modo, no instituto do qual se afirma independente - a propriedade."

Apesar da relação, não cabe ignorar a distinção, afinal, o proprietário pode conservar a sua propriedade, mesmo após a perda da posse (JHERING, 1974, p. 59). No entanto, o que parece mais interessante na teoria de Jhering (1974, p. 86), ao presente estudo, são as ponderações se a posse é um direito ou um fato. Para obter uma conclusão, Jhering (1974, p. 90) partiu do pressuposto de que "os direitos são interesses juridicamente protegidos" para

\footnotetext{
${ }^{7}$ Sobre a discussão dentre Savigny e Jhering, interessantes as pontuações de Caio Maio da Silva Pereira, em seu livro sobre direitos reais. Cf. PEREIRA, 2003, p. 15 e seguintes.
} 
43

concluir que a posse é um direito, afinal, "constitui a condição da utilização econômica da coisa". Eis as bases da teoria objetiva de Jhering sobre a posse, adotada pelo Brasil.

Dando sentido próprio à posse agrária, Getúlio Targino Lima a analisa com certas particularidades, quanto ao objeto aqui defendido (a terra) e à exigência do cumprimento de sua função social. Ponderando sobre a contenda entre Jhering e Savigny, em conjunto com o ordenamento brasileiro, concluiu que é difícil trabalhar com o conceito de posse agrária (LIMA, 1992, p. 58).

Refletindo sobre algumas de tais dificuldades conceituais, Marcos Alcino de Azevedo Torres (2008, p. 299-303) divide a posse em três categorias: a) a posse como conteúdo de certos direitos; b) a posse como requisito para aquisição de certos direitos e c) a posse por si mesma. Apesar de fazer a distinção dentro da posse, o autor realiza uma ponderação que muito interessa a este trabalho, para definir como elemento comum da posse, em todas as classificações que: "somente através dela é possível o exercício e o desenvolvimento de atividade humana sobre o solo" (TORRES, 2008, p. 300). Essa premissa precisa estar engranzada em qualquer estudo que se volte sobre a desapropriação para fins de reforma agrária.

É preciso entender que, no caso do imóvel, quanto ao seu cumprimento da função social, a tutela precisa estar voltada à posse. Isso é inerente às características do próprio instituto, afinal, "a propriedade sobrevive sem o exercício da posse, de forma abstrata com base no título aquisitivo. A posse não sobrevive sem a realidade de sua existência, não sendo razoável imaginar posse meramente abstrata" (TORRES, 2008, p. 303). ${ }^{8}$ Ora, em assim sendo, qual seria o sentido da inclusão no art. 6, I, da LC 76/93 da imediata imissão na posse pelo Poder Público? Parece simples concluir que a função social da propriedade tem relação direta e irrestrita com a posse.

Não basta, portanto, o elemento de existir a detenção anterior do proprietário, para obstar a transferência da posse ao Poder Público. É essencial levar em consideração a destinação econômica do bem também para aferir a defesa da posse. Exemplo de tal

\footnotetext{
${ }^{8}$ Apesar de não adotar as premissas da função social da propriedade, e sim se pautando na própria característica da desapropriação, Celso Bastos defende que a imissão na posse é o momento decisivo para a efetividade da desapropriação. Nesse sentido: Na prática, a imissão provisória na posse nada mais é do que uma antecipação da própria imissão no domínio, embora disfarçada com nome diverso. Cf. BASTOS, 1993.
} 
raciocínio é a modificação do Código Civil de 1916, em sua regulamentação da posse, em que restou superada a premissa quanto à defesa pura do domínio, com a nova redação do Código Civil de 2002:

O código Civil de 1916, em seu art. 505, dispunha que: "Não obsta à manutenção, ou reintegração na posse, a alegação de domínio, ou de outro direito sobre a coisa. Não se deve, entretanto, julgar a posse em favor daquele que a quem evidentemente não pertence o domínio". A segunda parte do dispositivo, cujo pressuposto era a evidência do domínio, talvez fundada no receio de sustentar a posse em qualquer circunstância, não mereceu acolhida no atual Código (art. 1.210, $2^{\circ}$ ), que, em boa hora, restituiu a coerência do sistema legal de tutela da posse, não mais restringindo com a exceptio domini (PEREIRA, 2003, P. 70).

Então, mesmo que endossada a aplicação do Código Civil, ou caso atendidas as particularidades da posse agrária, a tutela da posse, quanto ao cumprimento de sua função social não pode se restringir ao direito de propriedade. A posse, por sua própria essência de gozo, tem direta relação com o cumprimento da função social:

Se a propriedade se exerce pela posse, sendo esta indispensável no sistema adorado pelo código civil para a defesa daquela, como sua aparência ou como sentinela avançada, na expressão do autor da teoria prioritariamente adotada por nosso código e se, para dar cumprimento à função social da propriedade do imóvel, for necessário o exercício da faculdade de uso do bem e este uso só se materializar pela posse, ainda que indireta, conclui-se então que, na verdade, é a posse que tem função social e, através dela assim exercida, infere-se se o proprietário está cumprindo com o seu compromisso (proprietário) e aí estará ele alforriado das conseqüências do sistema para descumprimento da função social (TORRES, 2008, p. 304).

Então, o fenômeno da função social da propriedade tem direta relação com o fenômeno possessório. ${ }^{9}$ Tal como a propriedade, a posse deve ser vista em uma dimensão econômica social e ambiental, logo, a posse deve atender a determinados requisitos, cuja ausência pode conduzir à expropriação-sanção (MARQUESI, 2009, p. 55). Diante de tal premissa, Marcos Alcino de Azevedo Torres (2008, p. 309) prega que a posse correspondente à função social e deve prevalecer frente à posse inerte ou a posse simples, o que merece a conferência pelo sistema de uma proteção especial. De forma sintética, Roberto Wagner

\footnotetext{
${ }^{9}$ Concorda com tal premissa: ZAVASCKI, 2002, p. 844 e MARÉS, 2003, p. 116. 
45

Marquesi (2009, p. 123) chega à conclusão endossada neste trabalho: "a chamada função social da propriedade agrária esconde, na real verdade, a função social da posse".

Indo ainda mais longe na construção de tais conceitos, Carlos Frederico Marés (2006, p. 75) defende que a verdadeira sanção pelo descumprimento da função social da propriedade é a perda de sua proteção possessória. Para o autor, a desapropriação por interesse social para fins de reforma agrária deve ser compreendida como política pública e deve ser premissa de qualquer tutela que o proprietário pretenda obter em juízo. Então, "ao propor uma ação judicial deverá antes que qualquer outra prova, demonstrar o cumprimento da função social, o que, aliás, em geral é muito simples, basta produzir, ter relação de trabalho legais e manter as reservas legais e áreas de preservação ambiental protegidas (...)" (MARÉS, 2006, p. 74). Em outras palavras, defende que a avaliação do cumprimento da função social deveria ser preliminar a qualquer outra demanda que envolvesse a propriedade.

Por todos os elementos até aqui desenhados, este estudo defende que a posse deve ser vista como um direito, mas, em conjunto com os requisitos do cumprimento de sua função social, para que seja viável a sua defesa em juízo. Não basta a existência em abstrata do direito possessório, pois sua observação deve se dar em conjunto com a sua finalidade e, quando realizada dentro do procedimento agrário expropriatório, em consonância com a realização da política de reforma agrária.

Esclarecidos os contornos da posse, merece ser em seguida estudada a possibilidade de sua antecipação.

\subsection{A antecipação da tutela}

Passada a análise sobre a conotação da posse, conjugada com a noção sobre a função social da propriedade e a finalidade de reforma agrária, a este trabalho parece necessário desenvolver o lado processual da questão da imissão liminar na posse. O próximo passo parece certo: o contraditório especial, o rito sumário e a determinação de imissão preliminar na posse. Tais temas são de natureza processual e constituem o cerne do presente estudo, pois podem conceder efetividade à política pública.

Para tanto, parte-se da noção da concessão da tutela jurisdicional, como corolário do acesso ao Judiciário, ou seja, como mecanismo a ensejar a apreciação de qualquer lesão ou 
ameaça de direito $^{10}$ (ZAVASCKI, 2007, p. 5). Essa tutela jurisdicional, como parece simples concluir, pode ser deferida em benefício do particular, mas também do Poder Público, desde que exista a provocação do interessado. A apreciação da tutela, em última análise, significa “formular juízo sobre a existência dos direitos reclamados e, mais que isso, impor as medidas necessárias à manutenção ou reparação dos direitos reconhecidos” (ZAVASCKI, 2007, p. 6).

Trabalhando sobre a cognição no processo civil, Kazuo Watanabe (1987, p. 84) propõe a sua divisão em dois planos: o horizontal e o vertical. No primeiro deles, a cognição pode ser plena ou limitada, quanto à análise do todo ou de parte do conflito. No plano vertical, a cognição pode ser exauriente ou sumária, a depender do grau de profundidade em que será realizada. ${ }^{11}$ Trazendo tal perspectiva, para as ações possessórias (que detém estreita relação com este estudo), Teori Albino Zavascki defende que aqui ocorrem limites quanto à cognição horizontal, mas, sem restrição de profundidade:

Nesses procedimentos especiais, fixam-se, inclusive, limites à cognição no plano horizontal, ou seja, restringe-se o campo das pretensões de direito material e, conseqüentemente, das alegações de defesa, sem que isso importe, contudo, restrições ao grau de profundidade da cognição que permanece verticalmente integral. Há, em tais casos, cognição parcial (no plano horizontal) e exauriente (no plano vertical). É o que ocorre, por exemplo, na ação possessória, ou na ação de consignação em pagamento, nas quais a extensão do debate é limitada pela parcialização do conflito (cognição limitada), mas o nível de cognição é integral (cognição exauriente) (ZAVASCKI, 2007, p. 20).

Mais especificamente, no processo de desapropriação para fins de reforma agrária que inegavelmente envolve a tutela da posse - a cognição no plano horizontal é parcial, por opção do legislador (art. $9^{\circ}$, da LC n. 76/93). Como defende Luiz Guilherme Marinoni (2004, p. 32), pode-se notar então o conteúdo ideológico do procedimento, ao se eleger uma cognição parcial. O que se prestigia aqui, segundo o autor, são a certeza e a celeridade, ao permitir o surgimento da coisa julgada material, em menor tempo do que seria necessário à

\footnotetext{
${ }^{10}$ Tércio Chiavassa (2004, p. 44) defende que aqui se encontra o próprio fundamento constitucional para o reconhecimento da tutela de urgência e defende que no processo o tempo é "o grande inimigo de quem tem razão e, ao mesmo tempo, o grande aliado de quem não a possui”.

${ }^{11}$ Registre-se que quando Luiz Guilherme Marinoni trabalha a profundidade vertical de cognição, também com fulcro no trabalho de Kazuo Watanabe, apresenta as seguintes classificações para este plano: exauriente, sumária ou superficial. Logo, inclui na classificação a categoria superficial. Cf. MARINONI, 2004, p. 31. Contudo, para este trabalho a divisão doutrinária a ser empregada será a formulada por Kazuo Watanabe.
} 
47

análise de toda a extensão litigiosa (MARINONI, 2004, p. 32). Trazendo a cognição horizontal parcial para o mundo das desapropriações para fins de reforma agrária, Juraci Guimarães Júnior (2006, p. 37) explica que “A cognição do processo de desapropriação por interesse social, para fins de reforma agrária, é, portanto, parcial, pois, por expressa opção do legislador, foi excluída da matéria cognoscível na ação de desapropriação a discussão acerca da produtividade do imóvel". ${ }^{12}$

Pautado na cognição, o que o autor pretende com a ida ao judiciário é uma cognição exauriente, que persegue o juízo mais próximo da certeza jurídica, mas isso não impede que a cognição, no âmbito horizontal, seja parcial. Essa não deixa de ser uma tutela definitiva (ZAVASCKI, 2007, p. 27). Contudo, algumas vezes, os fatos conspiram contra a demora inerente à tutela definitiva, o que deu ensejo à criação da tutela provisória (ZAVASCKI, 2007, p. 28). Sem essa qualificação, a tutela pode se tornar inútil. Note-se, "tutelar tardiamente é quase o mesmo que não tutelar" (SANT'ANNA, 2003, p. 82).

A tutela antecipada é definida por Luiz Guilherme Marinoni como um meio de corrigir o equívoco na distribuição do ônus do tempo processual, não impondo este apenas ao autor. É instrumento moderníssimo que abre oportunidade para a efetividade do processo (MARINONI, 2004, p. 29). O autor resume o fenômeno como característico da modernidade:

A proliferação das tutelas sumárias nada mais é do que o fenômeno oriundo das novas exigências de uma sociedade urbana de massa que não mais admite a morosidade jurisdicional imposta pela ordinariedade. A redescoberta das tutelas sumárias anteriores à Revolução Francesa sob as vestes da tutela cautelar, assim, decorre da não adaptação do sistema de distribuição de justiça à evolução da sociedade (MARINONI, 2004, p. 14).

A leitura doutrinária do artigo $6^{\circ}$, da LC 76/93, que impede a imissão na posse do

INCRA, como primeiro provimento, sem atentar para o contraditório especial, torna sem qualquer efeito o pretendido rito sumário da medida. Nesse sentido, Juraci Guimarães Júnior (2006, p. 40) explica:

[...] seria desarrazoado entender que o legislador estabeleceu uma técnica de cognição parcial para o processo de desapropriação por interesse social, para fins de reforma agrária, com a finalidade de

\footnotetext{
${ }^{12}$ Como outros exemplos, no ordenamento, de cognição parcial, o autor cita o processo de conversão da separação em divórcio (art. 36, parágrafo único, da lei n. 6.515/77), embargos de terceiros (artigo 1.054 do CPC) e o processo de busca e apreensão da lei de alienação fiduciária (art. $3^{\circ}$, parágrafo $2^{\circ}$, do decreto-lei n ${ }^{\circ} 911 / 69$ ). 
sumarizar seu procedimento, e, pela simples propositura de uma ação declaratória de produtividade, pudesse ser suspensa a imissão do INCRA no imóvel ação de desapropriação.

Seria tornar sem qualquer efeito a celeridade pretendida no processo expropriatório, caso a tutela fosse condicionada à decisão final em outro procedimento judicial. $\mathrm{O}$ rito sumário transforma-se em procedimento mais oneroso do que o ordinário, pois apesar de seu objeto ser parcial, além de seu próprio trâmite (sobre a expropriação), deverá aguardar o desfecho que outro processo ordinário terá (em que se discute a produtividade). Então, um meio de evitar tal ineficiência será a tutela antecipada da posse.

Ocorre que é da essência das tutelas de urgência a sua provisoriedade, limitada no tempo, e a sua vinculação com a tutela definitiva (ZAVASCKI, 2007, p. 32). Adotada no nosso sistema processual, com especial ênfase após a reforma de $1994^{13}$, a tutela antecipada prevista no artigo 273 do CPC significa satisfação antecipada dos efeitos da tutela. É a realização dos direitos, que se mostrou essencial com a evolução da sociedade e diante da demora do procedimento comum (MARINONI, 2004, p. 124). O que se antecipa são os efeitos práticos daquela tutela (BUENO, 2007, p. 50). Logo, ela ocorre no mundo dos fatos. Em outras palavras, a urgência, o dano e o periculum in mora, estão no mundo dos fatos (ZAVASCKI, 2007, p. 51). Dá-se, assim, ao tempo do processo o seu efetivo valor, pois a maior efetivação do processo e a maior capacidade de eliminação do conflito só ocorrem quando mais prontamente for tutelado o direito do autor (MARINONI, 2002, p. 15).

Ora, exatamente calcado nas premissas de um processo mais célere, afeito às exigências da modernidade, que admite a antecipação de tutela, é que se pretende estudar o instituto do artigo 6, I, da Lei Complementar $n^{\circ}$ 76, de 1993. Intenta-se não só defender a antecipação como mecanismo apto a lidar com a distribuição do ônus decorrente do tempo no processo, mas também como opção do legislador quanto a uma cognição sumária e parcial da tutela possessória em desapropriação.

\footnotetext{
${ }^{13}$ Note-se que havia - como ainda há - enorme discussão sobre a equiparação das medidas cautelares à antecipação de tutela, com especial ênfase quanto à possibilidade de conceder em sede de medidas cautelares as tutelas satisfativas. Contudo, como o presente trabalho restringe-se a uma abordagem sobre a imissão na posse do artigo $6^{\circ}$, da Lei Complementar n. 76/93, foge do objeto do presente estudo abordar tal discussão doutrinária e jurisprudencial. Com a reforma da lei 10.444/2002, passou a ser incontroverso o cabimento de tutelas satisfativas no bojo da própria ação de conhecimento. Cf. ZAVASKI, 2007, p. 46. Sobre o tema, Athos Gusmão Carneiro $(2006$, p. 9) afirma que a consagração legislativa das tutelas antecipadas "além de impedir, doravante, a deturpação do uso da medida cautelar "inominada", veio a responder, como já referido, às exigências de equânime distribuição dos ônus do tempo no processo".
} 
Para o deferimento da imissão na posse prevista no art. $6^{\circ}$, I, da Lei Complementar 76/93, Weliton Militão (2001, p. 252) defende que é preciso ainda estarem presentes os requisitos necessários à concessão de liminar (fumus boni iuris e periculum in mora). $\mathrm{O}$ autor traça, portanto, um paralelo entre a previsão do rito sumário com os requisitos da tutela antecipada do artigo 273 do CPC. A mesma associação é feita pelo Judiciário, ao apreciar o dispositivo (art.6, I) da Lei Complementar $n^{\circ}$ 76/93, motivo pelo qual se faz necessária a apreciação de um dos óbices previstos no Código de processo Civil: a irreversibilidade da medida.

\subsubsection{A reversibilidade como óbice ao deferimento}

A instituição da tutela antecipada no processo, assim como as reformas que modificaram o Código de Processo Civil em 2002, tentaram reparar o equívoco de impor ao autor a espera de todo o trâmite processual para obter a tutela. Como já dito anteriormente, a tutela antecipada pretende rever "a distribuição do ônus do tempo no processo, cuja demora não mais deverá ser suportada somente pelo autor, mas também pelo réu, que agora tem contra si uma tutela antecipatória mais efetiva" (SANT'ANNA, 2003, p. 83). Constitui instituto que contribuirá para a restauração da igualdade no procedimento, pois permite entender que o tempo do processo não é um ônus do autor ${ }^{14}$. Nesse contexto, merece especial atenção a possibilidade de reversão da medida, como óbice à sua concessão antecipada. ${ }^{15} 16$

Segundo José Eduardo da Fonseca Costa, a reversibilidade pode ser entendida em três sentidos, para tornar um ato ineficaz, desde que: a) exista norma que garanta a reversibilidade lógico-jurídica ${ }^{17}$ (modelo francês); b) ocorra no mundo empírico, que ocorre

\footnotetext{
${ }^{14}$ MARINONI, Luiz Guilherme. A antecipação da tutela. $8^{\circ}$ Ed., São Paulo: Malheiros, 2004, p. 23.

${ }^{15} \mathrm{Cf}$. Art. $273, \S 4^{\circ}$, do CPC. Note-se que prestando atenção para o conteúdo do artigo, Marinoni defende que o artigo 273 fala em irreversibilidade do provimento, e não em "irreversibilidade dos efeitos fáticos do provimento". Ver: MARINONI, 2004, p. 223. Logo, defende a posição francesa (normativa) sobre a reversibilidade no sistema brasileiro.

${ }^{16}$ Cássio Scarpinella Bueno (2007, p. 64 e seg.) propõe como mecanismo para aferir a reversibilidade da medida a fórmula de Richard Posner como mecanismo hábil a verificar a probabilidade do direito do autor $(\mathrm{Pa}(\mathrm{Da})>(1-$ Pa) Dr). Contudo, não se adota tal mecanismo no presente estudo.

${ }^{17}$ Segundo explica o autor, o fenômeno aqui, na concepção francesa, se refere ao mundo normativo. Cf. COSTA, 2004, p. 57.
} 
no mundo dos fatos $^{18}$ (modelo inglês) e c) adote a conotação econômico-financeira (a possibilidade de a parte custear o efeito inverso).

Então, analisando o artigo 273, $\S 2^{\circ}$ (reversibilidade da tutela antecipada), o autor conclui que o sistema brasileiro adotou a figura da reversibilidade em seu significado sociológico ou econômico, e não sob o seu significado jurídico-normativo (COSTA, 2004, p. 55). Sua posição pode ser resumida assim:

Em verdade, sem dificuldades é possível falar em "satisfação provisória" caso se admita a existência de "sentenças liminares", isto é, de decisões que resolvam a relação jurídica material controvertida provisoriamente, respaldadas num mero juízo declarativo de verossimilhança. Com isto, todo o problema da provisoriedade reduzse ao trabalho de saber, simplesmente, se a realização prática da pretensão de direito material objeto do litígio é reversível ou irreversivel no plano fático, ou, sendo reversivel no plano dos fatos, se a parte beneficiária da tutela liminar tem condições econômicofinanceiras de custear a reversão (COSTA, 2004, p. 55).

O que José Eduardo da Fonseca Costa explica é que o Brasil adotou um sistema de reversibilidade que não se pauta apenas na existência de uma norma autorizando a tutela e do contexto fático. O sistema admite como reversibilidade a possibilidade de quem pretende a tutela, em caso de tal medida se comprovar indevida, custear a reversão de seus efeitos.

Em seguida, como proposta de reparação a uma possível sentença de indeferimento, o autor prega como soluções a prestação de caução e a responsabilização objetiva do autor (COSTA, 2004, p. 55). Defende que seja enfrentado o risco dos erros em razão da maior efetividade de direitos (MARINONI, 2004, p. 41). Quando aborda a situação peculiar da tutela antecipada a favor do Poder Público, assevera que não é exigível caução nessa hipótese, afinal, o erário público é suficiente para assegurar aos demandados a integral indenização (COSTA, 2004, p. 55). No entanto, na hipótese da tutela antecipada ser considerada indevida, com fulcro no artigo 811 do CPC, o autor defende a responsabilidade objetiva de indenizar ${ }^{19}$.

\footnotetext{
${ }^{18}$ Com certos temperamentos, essa é a posição acolhida por Bedaque (2003, p. 307), que defende que a tutela antecipada concede apenas satisfação fática e não jurídica. Contudo, como se apresentará ainda neste trabalho, o autor exige certas ressalvas quanto à reversibilidade.

${ }^{19}$ Merece registro que nem toda a doutrina endossa a aplicação do artigo 811 do CPC, como mecanismo inteligente para evitar o abuso no uso das cautelares. Ovídio Baptista (2009, p. 232), por exemplo, define que tal previsão é ao mesmo tempo incompleta e inconveniente. Afirma que a sua introdução no CPC decorre de um equívoco na interpretação das legislações processuais estrangeiras, que não acolheram a responsabilidade objetiva, mas sim a subjetiva.
} 
51

Esse raciocínio advém de uma aplicação analógica da responsabilidade objetiva do processo cautelar à tutela antecipada (COSTA, 2004, p. 55). Carreira Alvim (2006, p. 38-39) também entende que na hipótese de uso da tutela antecipada, que depois se apresente indevido, é cabível o dever de indenizar os danos causados pelo seu uso. Essa é uma forma de ver a reversibilidade.

Para Teori Albino Zavascki, a preocupação com a reversibilidade tem especial relação com o princípio da salvaguarda do núcleo essencial ${ }^{20}$. Mesmo assim, o autor admite a relativização de princípio, sob pena de se tornar sem efeito a existência da tutela antecipada. Reconhece que, perante o conflito da reversibilidade, seja dado o privilégio do direito provável em detrimento do improvável. E nessa tarefa, cabe ao juiz garantir, até onde for possível, a reversibilidade, e garantir a reparação de eventuais indenizações (ZAVASKI, 2007, p. 101). Como uma das vozes mais progressistas sobre essa posição mais liberal da reversibilidade, Luiz Guilherme Marinoni (2000, p. 123) defende que:

Não há qualquer lógica em não se admitir a concessão da tutela antecipatória baseada em 'fundado receio de dano irreparável ou de difícil reparação' sob o simples argumento de que a sua concessão pode causar prejuízo irreversível ao demandado. Mesmo antes da introdução da tutela antecipatória no Código de Processo Civil admitia-se a concessão de tutela antecipatória, sob o rótulo de tutela cautelar, ainda que ela pudesse causar prejuízo irreversível ao réu. (...).

Como está claro, nos casos em que o direito do autor, que deve ser mostrado como provável, está sendo ameaçado por dano irreparável ou de difícil reparação é ilógico não se conceder a tutela antecipatória com base no argumento de que ela pode trazer um dano ao direito que é improvável.

Para Marinoni (2004, p. 230), a "satisfatividade da tutela antecipatória - e mesmo a eventual irreversibilidade dos seus efeitos fáticos - não é contraditória com a sua estrutura". Isso porque, a tutela precisa ser vista diante das diversas possibilidades a que precisa servir, diante do direito material objeto da lide. Dando o exemplo dos direitos possessórios - que por coincidência também são o objeto deste trabalho - Marinoni (2004, p. 236) explica que a

\footnotetext{
${ }^{20}$ Segundo o autor, tal princípio merece ser prestigiado pois "antecipar irreversivelmente seria antecipar a própria vitória definitiva do autor, sem assegurar ao réu o exercício do seu direito fundamental de se defender, exercício esse que, ante a irreversibilidade da situação de fato, tornar-se-ia absolutamente inútil, como inútil seria, nestes casos, o prosseguimento do próprio processo. Cf. ZAVASCKI, 2007, p. 101.
} 
liminar de interditos possessórios pode produzir efeitos práticos irreversíveis. Mas, o simples fato de ser a tutela irreversível, não obsta o seu deferimento, afinal, a concessão ou a negação podem gerar efeitos irreversíveis para o autor também. Não se pode obrigar o juiz a provocar um dano ao direito que se vislumbra o mais provável, apenas porque quem o demanda é o autor.

Como outras palavras, essa mesma solução é defendida por José Roberto Bedaque (1997, p. 241), como meio de relativizar a irreversibilidade da medida, em casos extremos, pois "a indenização por perdas e danos preencheria o requisito da reversibilidade".

Diante da irreversibilidade, deve-se fazer uma ponderação quanto ao direito do autor, para definir se a tutela antecipada pode, ou não, ser antecipada. Nas palavras de José Eduardo da Fonseca Costa (2004, p. 55):

(...), para que o magistrado possa flexibilizar o rigor do $\S 2 .^{\circ}$ ao art. 273 do CPC, cabe-lhe aferir o grau de proporcionalidade entre dois riscos: os riscos decorrentes do deferimento e os riscos conseqüentes do não-deferimento da tutela. Se, num mesmo caso concreto, o indeferimento da tutela gerar risco de prejuízo irreversível ao direito do autor e o seu deferimento gerar perigo de irreversibilidade a uma reposição in natura da situação fática anterior, deverá o juiz sacrificar o direito improvável: não há sentido em sacrificar o direito provável ameaçado pelo dano iminente em nome de uma possível, mas improvável, situação de irreversibilidade.

A reversibilidade do artigo $273, \S 2^{\circ}$ do $\mathrm{CPC}$, não pode ser interpretada de maneira restrita, sob pena de tornar sem efeito o conteúdo do seu caput (2006, p. 38-39). Essa é exatamente a premissa em que se socorre este trabalho sobre a imissão na posse no bojo da desapropriação por interesse social para fins de reforma agrária. A reversibilidade precisa ser vista no sentido sócio-econômico, para admitir a imissão liminar (o que é cogente segundo o artigo 6, I, da Lei Complementar $n^{\circ}$ 76/93) e permitir assim a efetividade do assentamento e do programa de reforma agrária.

Quando aborda a possibilidade de tutela antecipada, no bojo de outra ação que permita a discussão sobre a produtividade da terra a ser desapropriada, Juraci Guimarães Júnior restringe a possibilidade do deferimento da tutela ao momento anterior à imissão na posse do INCRA. Afinal, depois desse momento ter-se-ia iniciado o processo de reforma agrária com o assentamento dos trabalhadores rurais no local. No entanto, em havendo a 
53

imissão, defende que em se comprovando em outro processo, que não o da desapropriação para fins de reforma agrária, vício no procedimento administrativo, caberia aqui a conversão da desapropriação em indireta, com o correlato pagamento de indenização. Afirma que “(...) uma vez comprovada a ilegalidade no processo administrativo, a desapropriação se converteria em indireta, devendo o valor indenizatório ser integralmente pago em dinheiro, conforme já decidiu o Supremo Tribunal Federal’(GUIMARÃES JÚNIOR, 2006, p. 41). Então, a desapropriação por interesse social, quanto à imissão liminar na posse, detém reversibilidade, afinal, caso se comprove que a expropriação era indevida, caberá a quem for prejudicado, o pagamento de indenização sob o trâmite de uma desapropriação indireta.

Em outras palavras, a tutela da posse concedida na ação de desapropriação para fins de reforma agrária é reversível, pois, caso se ateste que a terra era produtiva, seria viável o pagamento de indenização por meio de desapropriação indireta, com fundamento no artigo 35 do Decreto-Lei n ${ }^{\circ} 3361$, de 1941.

Por as razões até aqui apresentadas, bem se vê que é exatamente a posição mais moderna quanto à tutela antecipada e à reversibilidade a defendida neste trabalho. Deseja-se incitar o enfrentamento do risco em prol da efetividade do direito social e da política pública. "Não há razão para a timidez no uso da tutela antecipatória, pois o remédio surgiu para eliminar um mal que já está instalado, qual seja a morosidade judicial. Em muitas hipóteses, não pode haver efetividade sem riscos (MARINONI, 2004, p. 24). O risco é ainda mais grave, como se apresentará, quando se submete o procedimento expropriatório - que detém contraditório especial e rito sumário - à espera do trânsito em julgado de outra ação em que se discutirá a produtividade da terra. Em outras palavras, a política pública de assentamento é retardada em muitos anos, sob a chancela de que a imissão na posse é um mal ao direito particular, posto que se trata de medida irreversível.

No entanto, como se apresentou neste capítulo, a reversibilidade pode ter leituras variadas. Na modernidade, diante da morosidade judicial, da política social em jogo e da opção legislativa cogente, o que se espera é que se assuma o risco, conforme a reversibilidade econômico-financeira, imitindo o Poder Público na posse, e ao mesmo tempo garantindo a reparação caso tal medida de urgência se mostre, no futuro, indevida. 


\subsection{Panorama fático. INCRA e IBGE}

Apesar de existirem vozes em contrário ${ }^{21}$, o retardamento, em função do indeferimento da imissão na posse nas desapropriações por interesse social para fins de reforma agrária é um problema a ser considerado em uma leitura sobre tal política pública. Então, para se compreender o objeto do presente trabalho, defende-se que não basta uma delimitação da tutela possessória quanto aos seus limites e características. Da mesma forma, não adianta se restringir a apontar e trabalhar os conceitos próprios da lei complementar que versa sobre a desapropriação social para a reforma agrária. É preciso, ainda, verificar quais os efeitos práticos das medidas processuais e como se encontra o quadro atual das imissões na posse, referente à desapropriação por interesse social para fins de reforma agrária no Brasil.

Segundo os dados oficiais do IBGE, obtidos no Censo agropecuário realizado em 2006, se comparados os períodos de 1997 a 2006 (anos em que o censo foi efetuado) o Brasil teve um aumento no número de hectares de lavouras de 41.794 .455 para $76.697 .324 .^{22}$ Os números mostram que a produção quase dobrou, o que demonstra que o país tornou-se mais produtivo no setor agropecuário. Outro indicativo do IBGE interessante para o presente estudo é o de que a agricultura brasileira continua predominantemente familiar, afinal, dentro do item "pessoal ocupado", 12.910 .591 pessoas detêm laços de parentesco com o produtor, enquanto 3.557 .042 não possuem tal vínculo. Isso significa que mesmo com o crescimento do agronegócio, a produção agrícola familiar brasileira ainda é a atividade predominante no setor.

De acordo com o I Censo de Reforma Agrária, INCRA, CRUB e UNB, o Brasil ainda detém um cenário de 4,5 milhões de famílias sem-terra. Isso expressa que na estimativa realizada entre dezembro de 1996 a janeiro de 1997, encontrou-se como demanda de famílias

\footnotetext{
${ }^{21}$ Em uma análise de caso, para a formulação de um Parecer contratado por particular (A. PAROLIN \& Cia Ltda.), Juarez Freitas (2007, p. 83 e seg.) faz sérias críticas à atuação judicial do INCRA em ação de desapropriação por interesse social para fins de reforma agrária, para qualificar a atuação da Autarquia como agente de "movimentos evasivos" e que "dá de ombros e cruzou os braços" quanto ao cumprimento da decisão. Quando tratou sobre a imissão na posse, classificou o sistema expropriatório assim: "As lides expropriatórias são, não raro, assim: céleres para o Poder expropriante, lentas, muito lentas, para o proprietário."

22 IBGE. Censo Agropecuário $2006 . \quad$ URL:

http://www.ibge.gov.br/home/estatistica/economia/agropecuaria/censoagro/2006/agropecuario.pdf. Acesso em 4.4.2010.
} 
55

a serem assentadas o quantitativo de 4,5 milhões. ${ }^{23}$ Frise-se que o número se refere a famílias, e não a pessoas, o que demonstra o tamanho do desafio.

Quanto à concentração de terras, um recenseamento de 1980 revelou que $45 \%$ das terras brasileiras estavam concentradas em menos de $1 \%$ dos estabelecimentos rurais. Segundo o mesmo estudo, metade dos estabelecimentos agrícolas existentes no Brasil produz em apenas 2,4\% das terras nacionais. Há ainda, de acordo com a pesquisa, no Brasil 80 milhões de hectares de terras ociosas (REIS, 2004, p. 113). Esse quadro endossa o quanto ainda é urgente e necessária a efetivação da política de reforma agrária no Brasil.

Com o aumento da preocupação com a efetividade da reforma agrária, o CNJ Conselho Nacional de Justiça - requereu ao INCRA um análise do quadro de óbices processuais à efetivação da tutela para a reforma agrária. Como resposta o INCRA verificou que em decorrência de óbices processuais (impedimento de imissão na posse) $\mathbf{1 2 . 0 6 3}$ (doze mil e sessenta e três famílias) não estão em assentamentos.

Esse quadro dos óbices processuais foi apresentado em 2009, no evento organizado pelo CNJ, no intuito de tornar efetivo um mutirão em processos agrários para garantir celeridade à política pública. O evento ocorreu em 07.12.2009, em Marabá, e identificou como um dos maiores óbices à efetivação da reforma agrária o impedimento da imissão na posse.

Como as desapropriações para fins de reforma agrária tem se apresentado como complexas e de improvável êxito no Poder Judiciário, o INCRA tem optado, em certas áreas, pela compra direta de terras produtivas, ao invés da expropriação. Isso decorre das dificuldades de encontrar áreas a serem desapropriadas na sul e sudeste do país, além da ineficiência da desapropriação por interesse social para fins de reforma agrária caso o imóvel não esteja abandonado (RODRIGUES, 2009). Como os procedimentos judiciais para a desapropriação não são tidos como válidos perante o Judiciário, tornando o procedimento moroso e difícil, a Autarquia tem preferido a aquisição direta das terras, ao invés de enfrentar o litígio. Torna-se, portanto, sem efeitos práticos, ou melhor, com efeitos mais danosos à política pública do que benéficos, a pretensão do artigo 184 da CF (a desapropriação por interesse social para fins de reforma agrária).

\footnotetext{
${ }^{23}$ I Censo de Reforma Agrária, INCRA, CRUB e UNB. Dados recolhidos entre dez. 1996 e jan. 1997. 
Cabe mencionar que o programa de reforma agrária detém importância não só como meio de redistribuição de terras, mas também como mecanismo de pacificação social. Apesar de ainda não ter resolvido o problema da violência no campo, estudos mostram que o aumento de assentamento gerou uma redução no número de mortes. Em 2003, 42 (quarenta e duas) pessoas morreram por conflito no campo. Em 2009, foram 10 (dez) o número de óbitos diante do maior número de assentamentos. ${ }^{24}$

Todo esse contexto leva à conclusão de que o problema da ineficiência da imissão da posse nas desapropriações é uma dificuldade atual e grave, que detém como conseqüência uma redução da efetividade da política pública. O cenário fundiário brasileiro continua sendo desigual e excludente, carecendo de uma política pública que possa reverter esse quadro, de maneira efetiva.

Todo esse quadro leva a crer que é necessária uma reflexão sobre a desapropriação por interesse social para fins de reforma agrária e a celeridade e eficiência de seu procedimento.

\section{CONCLUSÃO}

Quando a Constituição Federal previu os mecanismos para a efetivação de uma política pública agrária (art. 184 - desapropriação por interesse social para fins de reforma agrária), o simples ato de inserir tal previsão no texto constitucional não livrou os seus cidadãos de sua efetividade (CARVALHO NETTO, 2003). Não basta o texto propor a política e delimitar os seus mais minuciosos contornos e os direitos a concretizar. É preciso também conferir efetividade aos dispositivos, por iniciativa nossa, dos cidadãos. ${ }^{25} \mathrm{O}$ texto apenas inaugura o desafio.

\footnotetext{
${ }^{24}$ Cf. INCRA. REFORMA AGRÁRIA: Terra, qualidade de vida e cidadania no meio rural. Brasília: Publicação Especial do Instituto Nacional de Colonização e Reforma Agrária, 2010, março, p. 6.

${ }^{25}$ Marcelo Cattoni (2002) trata sobre esse desafio quando explora a visão derrotista, de juristas que vêem frustrados "os "ideais não realizados" da Constituição brasileira de 1988, o que leva de modo sinistro a celebrar um réquiem para o projeto constitucional brasileiro." Explica que por não encararem o desafio imposta pela realidade, propõem sucessivas reformulações constitucionais, como se tais alterações resolvessem por si o problema da realidade social.
} 
Os princípios que estão contidos no artigo 184 da Constituição Federal foram detalhadamente regulamentados pela Lei Complementar n. 76, de 1993, com um dispositivo expresso, quanto à escolha legislativa de que a imissão na posse em favor do Poder Público deve ser imediata. Contudo, mais uma vez, a norma geral e abstrata não pôs fim ao problema social. ${ }^{26}$ A existência singular da norma não resolveu o problema social.

A diferença no contexto da realidade social deve advir de um olhar mais amplo sobre o problema, no olhar da sociedade e de quem julga. Os caminhos para a mudança da realidade fundiária brasileira já estão no ordenamento (CF e LC 76/93), que não carece de qualquer nova alteração ou reforma constitucional. O que poderia ser feito - e se propõe neste estudo é uma releitura dos mesmos institutos com uma lente mais progressista de seus propósitos, o que merece ser feito não só pelo Judiciário, mas, sobretudo pela sociedade. A tarefa pode ser cumprida por cidadãos, que não só compreendem a importância e a extrema necessidade de uma política de reforma agrária em um país de desigualdades sociais como o Brasil, mas também a defendem de pensamentos e atos conservadores.

\section{REFERENCIAS}

ALBURQUEQUE, Marcos Prado. O Direito Agrário na Constituição (obra coletiva). Rio de Janeiro: Forense, 2005.

ALVIM, J. E. Carreira. Tutela antecipada. $5^{\circ}$ ed. Curitiba: Juruá, 2006.

BARBOSA, Rui. Posse de Direitos Pessoais. $2^{\circ}$ ed. Rio de Janeiro: Simões Editor, 1959.

BASTOS, Celso. Desapropriação e imissão provisória na Constituição de 1988. In Revista de Direito Constitucional, Vol. 4, jul-set, 1993.

BEDAQUE, José Roberto dos Santos. Tutela Cautelar e Tutela Antecipada: Tutelas Sumárias e de Urgência. $3^{\circ}$ ed., São Paulo: Malheiros, 2003.

BEDAQUE, José Roberto. Considerações sobre a antecipação da tutela jurisdicional. In Teresa Arruda Alvim Wambier (Coord.). Aspectos polêmicos da antecipação de tutela. São Paulo: Revista dos Tribunais, 1997.

BORGES, Antonio Moura. Curso Completo de Direito Agrário. $2^{\circ}$ ed., Leme: Edijur, 2007.

BORGES, Paulo Torminn. Estatuto da Terra com a legislação pertinente ementada, São Paulo: Pro-livro, 1979. BUENO, Cássio Scarpinella. Tutela antecipada. $2^{\circ}$ ed., São Paulo: Saraiva, 2007.

CARNEIRO, Athos Gusmão. Da antecipação de tutela. $6^{\circ}$ ed., Rio de Janeiro: Forense, 2006.

\footnotetext{
${ }^{26}$ Sobre a ingenuidade do pensamento de que a lei é o mais alto grau de racionalidade, pois ela é a abstrata e genérica, Vide: SOARES, 1986, p. 69. 
CARVALHO NETTO, Menelick de. A Hermenêutica constitucional e os desafios postos aos Direitos Constitucionais. SAMPAIO, José Adécio Leite (Org.). In Jurisdição Constitucional e Direitos Fundamentais. Belo Horizonte: Del Rey. 2003.

CHACÓN, Enrique Ulate. Apuntes para uma Teoria General del derecho procesal agrario (Antecedente, importancia y Contenido). In Revista de Direito Agrário, ano 16, n. 14, dez, 2000.

CHIAVASSA, Tércio. Tutelas de urgência cassadas. São Paulo: Quartier Latin, 2004.

COSTA E SILVA, Antônio Carlos. Processo de desapropriação e procedimentos de desapropriação consensual. $2^{\circ}$ ed., São Paulo: Sugestões Literárias, 1980.

COSTA, José Eduardo da Fonseca. Tutela antecipada: irreversibilidade, caução e responsabilidade objetiva. In. Revista do Processo. v. 115, Mai-jun, 2004.

ENTERRÍA, Eduardo G.; FERNANDEZ, Tomás-Ramon. Curso de Derecho Administrativo II, $4^{\circ}$ ed., Madrid: Civitas, 1997

FIGUEIREDO, Lúcia Valle. Curso de direito administrativo. 6. ed., São Paulo: Malheiros, 2002.

FREITAS, Juarez. Desapropriação-Sanção por Interesse Social para fins de Reforma Agrária. Ação ajuizada há mais de 20 anos. Indenização. Títulos da Dívida Agrária (Parecer). In Revista Interesse Público, Belo Horizonte: Fórum, ano 9, n. 45, set./out., 2007.

GUIMARÃES JÚNIOR, Juraci. A cognição no processo de desapropriação de desapropriação para fins de reforma agrária. In Revista de Direito Agrário. ano 19, n. 18, 2006.

HARADA, kiyoshi. Desapropriação: doutrina e prática. $7^{\circ}$ ed., São Paulo: Atas, 2007.

I Censo de Reforma Agrária, INCRA, CRUB e UNB. Dados recolhidos entre dez. 1996 e jan. 1997.

IBGE. Censo Agropecuário 2006. Obtido via internet. Disponível em: http://www.ibge.gov.br/home/estatistica/economia/agropecuaria/censoagro/2006/agropecuario.pdf. Acesso em 4.4.2010.

INCRA. PFE quer evitar reintegração de posse em terras da união e áreas que não cumprem a função social. 07.12.2009. Obtido via internet. Disponível em: http://www.incra.gov.br/portal/index.php? option=comcontent\&view $=$ article \&id =13650:pfe-quer-evitar-reintegracao-de-posse-em-terras-da-uniao-eareas-que-nao-cumprem-a-função-social\&catid=380: noticias \&Itemid=316. Acesso em 27.03.2010.

INCRA. REFORMA AGRÁRIA: Terra, qualidade de vida e cidadania no meio rural. Brasília: Publicação Especial do Instituto Nacional de Colonização e Reforma Agrária, 2010, março.

JHERING, Rudolf Von. A Teoria Simplificada da posse. Trad. Vicente Sabino Junior. São Paulo: Bushatsky: 1974.

LIMA, Getúlio Targino. A posse agrária sobre bem imóvel: implicações no direito brasileiro. São Paulo: Saraiva, 1992.

LISBOA, Roberto Senise. Manual de Direito Civil, volume 4: direitos reais e direitos intelectuais. $3^{\circ}$ ed., São Paulo: Revista dos Tribunais, 2004.

MARÉS, Carlos F.A função social da terra. Porto Alegre: Sérgio A Fabris Editor, 2003.

MARÉS, Carlos Frederico. Desapropriação sanção por descumprimento da função social?. In Revista de Direito Agrário. ano 19, n. 18, 2006.

MARINONI, Luiz Guilherme. A antecipação da tutela. $8^{\circ}$ ed., São Paulo: Malheiros, 2004.

MARINONI, Luiz Guilherme. Novas linhas do processo civil. $4^{\circ}$ ed., São Paulo: Malheiros, 2000.

MARINONI, Luiz Guilherme. Tutela antecipatória e julgamento antecipado: parte incontroversa da demanda. $5^{\circ}$ ed., São Paulo: Revista dos Tribunais, 2002.

MARQUESI, Roberto Wagner. Direito reais agrários \& Função Social. $2^{\circ}$ ed., Curitiba: Juruá, 2009.

MELLO, Celso Antônio Bandeira de. Curso de direito administrativo. 14. ed., São Paulo: Malheiros, 2002.

MENDES, Gilmar Ferreira; COELHO, Inocêncio Martins; BRANCO, Paulo Gustavo Gonet. Curso de Direito Constitucional. São Paulo: Saraiva, 2007.

MIRANDA, Gursen de A. Direito Agrário e Ambiental: a conservação dos recursos naturais no âmbito agrário. Rio de Janeiro: Forense, 2003.

NOBRE JÚNIOR, Edilson Pereira. Desapropriação para fins de reforma agrária. $3^{\circ}$ ed. Curitiba: Juruá, 2006.

OLIVEIRA, Luciano. Não fale do Código de Hamurabi! A pesquisa sócio-jurídica na pós-graduação em direito. In Sua Excelência o Comissário e outros ensaios de sociologia jurídica. Rio de Janeiro: Letra Legal, 2004.

OLIVEIRA, Marcelo Andrade Cattoni de. Direito Constitucional. Belo Horizonte: Mandamentos, 2002.

PEREIRA, Caio Maio da Silva. Introduções de Direito Civil. Rio de Janeiro: Forense, 2003. 
59

REIS, Gláucia Maria Teodoro. Reforma Agrária como desenvolvimento econômico. In. Direito Agrário Contemporâneo. Lucas Abreu Barroso e Cristiane Lisita Passos (Org.) Belo Horizonte: Del Rey, 2004.

RODRIGUES, Flávio. Governo compra mais terras do que desapropria. Brasília: INCRA, 2009. Obtida via internet. Disponível em: http://www.incra.gov.br/portal/index.php?option=com content\&view=article\&id=13710:governo-compra-mais-terras-do-que-desapropria\&catid=321:incra-namidia\&Itemid=305. Acesso em 26.03.2010.

SABINO JÚNIOR, Vicente. Da desapropriação: doutrina, legislação, jurisprudência, prática. São Paulo: José Bushatsky, 1972.

SALlES, José Carlos de Moraes. A Desapropriação à luz da doutrina e da jurisprudência. $5^{\circ}$ ed. São Paulo: Revista dos Tribunais, 2006.

SANCHES, Cid Roberto de Almeida. Natureza do decreto presidencial que declara área de interesse social para fins de reforma agrária. In Revista de Direito Agrário. Ano 20, n. 19, 2007.

SANT'ANNA, Paulo Afonso de Souza. Novos contornos do instituto da tutela antecipada e os novos paradigmas do sistema processual civil (lei 10.444/2002). In Revista do processo, v. 112, out-dez, 2003.

SANTOS, Weliton Militão dos. Desapropriação, reforma agrária e meio ambiente: aspectos substanciais e procedimentos. - Reflexo no Direito Penal. Belo Horizonte: Mandamentos, 2001.

SCIORILLI, Marcelo. Direito de Propriedade: evolução, aspectos gerais, restrições, proteção, função social; Política agrária: conformação, instrumentos, limites. São Paulo: Juarez de Oliveira, 2007

SILVA, José Afonso da. Curso de Direito Constitucional Positivo. $21^{\circ}$ ed. São Paulo: Malheiros, 2002.

SILVA, Ovídio Baptista da. Do processo cautelar. Rio de Janeiro: Forense, 2009.

SILVA, Ovídio. A Baptista da. Ação cautelar inominada no direito brasileiro. $3^{\circ}$ ed., São Paulo: Forense, 1991. SOARES, Rogério Ehrhardt. O conceito ocidental de constituição. In: Revista de legislação e jurisprudência, Coimbra, ano 119, nº 3743, 01 jun. 1986, e n 3744, 01 jul. 1986.

SUNDFELD, Carlos Ari. Desapropriação. São Paulo: Revista dos Tribunais, 1990.

TORRES, Marcos Alcino de Azevedo. A propriedade e a posse: Um confronto em torno da Função Social. $2^{\circ}$ ed, Rio de Janeiro: Lúmen Júris, 2008.

WATANABE, Kazuo. Da cognição no processo civil. São Paulo: Revista dos Tribunais, 1987.

ZAVASCKI, Teori Albino. A Tutela da posse na Constituição e no Projeto do Novo Código Civil. In. $A$ reconstrução do direito privado. Judith Martins-Costa (org). São Paulo: Revista dos Tribunais, 2002.

ZAVASCKI, Teori Albino. Antecipação da Tutela. $5^{\circ}$ Ed., São Paulo: Saraiva, 2007.

Artigo recebido em 06 de março de 2012 e aceito em 22 de abril de 2012.

R. Fac. Dir. UFG, V.36, n. 01, p. 35-59, jan./jun. 2012 ISSN $0101-7187$ 